\title{
Fejős, Zoltán. 2020. “Kaper Kóntri.” Magyar rézbányászok Amerikában ("'Kaper Kóntri.” Hungarian Copper Miners in America'). Budapest: Korall. 286 pp.
}

\section{Reviewed by László Kürti, University of Miskolc, Hungary, bolkurti@uni-miskolc.hu}

Kaper Kóntri (henceforth Copper Country) is the first book-length study of Hungarian immigrants who during the first two decades of the twentieth-century worked in the copper mines in the Keweenaw Peninsula, the northernmost part of Michigan's Upper Peninsula. It offers a variety of topics in social history and ethnography that run the gamut from genealogy, company statistics, mine accidents, strikes, foodways and religious strife. It has nine substantive chapters, photographs, three maps, and references cited. The author, Zoltán Fejös, is an ethnographer-folklorist and former director of the Ethnographic Museum in Budapest, known for scholarly work on Hungarian immigrant settlements and traditions in the United States. Copper Country and Fejös's earlier books, A chicagói magyarok két nemzedéke, 1890-1940 ['Two Generations of Hungarians in Chicago, 1890-1940'] (1993), and "Mert abban az idöben lehetett vándorolni": A cigándi amerikások emlékezete ['"Because at The Time It Was Possible to Emigrate": Remembering Emigrants from Cigánd to America'] (2017), complement one another sufficiently but not completely.

Throughout Chapters 1-3, Fejös provides the historical context for the establishment of Hungarian copper-mining camps in the counties of Houghton and Keweenaw, where between 1907 and 1914 immigrants from the Austro-Hungarian Monarchy were settling. Subsequently, in Chapters 4-7, he recounts how immigrants and their families established bases of community life with social, religious, and cultural organizations, a process that during these early years was visible in other ethnic communities, as well. In Chapter 8, perhaps the most successful one because its topic has been extensively researched by American labor historians, Fejös documents political strife by focusing on the copper strike of 1913-1914, in which Hungarians actively participated. Subsequently, this event, perhaps more than anything else, forecasted the impending social disintegration of the miners' camp that was finalized by the economic slump following World War I. The remainder of the book is an appendix devoted to several newspaper articles and letters from 1913-1914, an explanation of abbreviations, bibliography, and captions of photographs and maps.

While it is not easy to summarize, let alone evaluate a study of this scope, I would hazard a few critical comments. The shifting time-frame of Copper Country is confusing at times. For instance, I fail to see how an interesting miner's narrative about ethnic family life collected from a grandson born in 1939 (!) can support any claim about actual immigrant experiences of the 1910s. Because of the dwindling number of Hungarians in the American copper industry, the Protestant congregation ceased to exist in 1919, and by 1920 there was no more an ethnic Hungarian community to speak of, as less than two hundred Hungarians remained in the two

(cc) BY

ULIS D-Serle 
Michigan counties analyzed (25). Then there is a matter of critical analysis or rather lack of it. For example, ministers in the immigrant settlements had a key role in organizing and leading community life, starting from family feasts and religious holidays and ending with recreational activities. However, the author does not refer to any possible social cleavage, perhaps even class antagonism, that probably existed between these learned clergy men and their working-class flock. As it happened, none of the Protestant pastors remained in the mine camps for a long period, and many of them abandoned their parishioners after a short while. One minister, for instance, justified his resignation from his religious duties with the excuse that he had to return to Hungary, when actually he went to serve another Hungarian community, in New York State, where he also studied for his theology diploma (131).

Fejős has amassed a plethora of genealogical and census data, passenger lists and burial records, all of which give the impression that his book came to fruition mainly by utilizing sources such as Ancestry.com, heritage.statueofliberty.org, FamilySearch.com, archives.gov, and findagrave.com. Since research on immigrants from more than one-hundred-years ago has its drawbacks, not the least of which is the lack or scarcity of written material, Fejös's historical reconstruction, rather ambitiously, aims at "verbalizing remnants of a sunken, entirely unknown world" ['elsüllyedt, teljesen ismeretlen világ emléknyomainak a megszólaltatásához'] (11-12). This approach seems to overshadow Copper Country because the sources cited in it make it more than obvious that the industrial region at its center is not and never was an unknown world. True, there are numerous and often tragic personal stories just like elsewhere in poverty-ridden industrial and mining communities of the era, but there is a dilemma when a scholarly approach results in compiling highly skewed primary sources and simply lets workers or elites speak for themselves. For instance, the author states that his research area was above all the country of contradictions (11). This rather general statement can be made just about any North American farming community, factory town or coal patch during the tumultuous decades of the last century. Remarks such as that communal living in boarding houses was not entirely without problems, and that in this region the presence of single women was extremely rare are equally vague (63-64). Equating boarding-house folklore with actual cases of conflicts created in such crowded places limits the range of vision here. Regrettably, Fejös does not cite any police records or court transcripts that would support his case, and anyone familiar with the literature of everyday life of the early immigrants may wonder why the author did not follow in the footsteps of the milestone sociological study of Erdmann D. Beynon on Hungarian criminality in Detroit published in 1935.

More of a somber postscript than an actual chapter, Chapter 10 concludes that the history of Hungarian-America will only be known if people read books such as Copper Country, and the memory of immigrants will stay alive mostly in the minds of the descendants of the old country (242). The fact is, and I can attest for that from my own fieldwork experience, that many thirdfourth generation descendants eagerly remember fanciful stories of their ancestors, especially folklore of the bygone days, without thorough historical aspirations. Finally, I only ask the readers to look at Fejös' excellent Chicago case-study, in which the photographs are far more central compared to those of Copper Country. Here, some unattractive color photos are reproductions of postcards, while some others are recent mediocre snapshots requiring adequate contrast, color, and tone correction (252-262). Black-and-whites suffer from similar mishandling as most of them depict blurred faces or are too small to enjoy; and an unreadable vintage newspaper page and a naturalization document are inadequate reproductions to be useful (69, 
$173,188)$. In conclusion, the question automatically offers itself: is this a good book? The answer depends on whether the reader is willing to take the abundant early literary and personal narratives for granted and avoid pondering on their actual meaning and utility. A competent and readable historical account of ethnic Americana, Copper Country will be valuable for those interested in the ethnographic aspects of early Hungarian-American working-class immigrant lives. However, the lack of tighter editing and theoretical and comparative insights, together with an inattentive choice of visual materials, both archival and current, mar this otherwise useful volume. 